\title{
Brown Tumors of the Anterior Skull Base as the Initial Manifestation of True Normocalcemic Primary Hyperparathyroidism: Report of Three Cases and Review of the Literature
}

\author{
Gerçek Normokalsemik Primer Hiperparatiroidinin İlk Bulgusu Olarak \\ Ön Kafatası Tabanının Kabverengi Tümörleri: $\ddot{U c ̧}_{c}$ Olgu Sunumu ve \\ Literatürün Gözden Geçirilmesi
}

\author{
Mahmoud Reza KHALATBARI ${ }^{1}$, Mehrdokht HAMIDI $^{1}$, Yashar MOHARAMZAD ${ }^{1}$, Ali SETAYESH ${ }^{2}$, \\ Abbas AMIRJAMSHIDI ${ }^{3}$ \\ ${ }_{1}^{1}$ Arad Hospital, Department of Neurosurgery, Tehran, Islamic Republic of Iran \\ ${ }^{2}$ Hazrate-Rasoul Hospital, Department of General Surgery, Tebran, Islamic Republic of Iran \\ ${ }^{3}$ Sina Hospital, Department of Neurosurgery, Tehran, Islamic Republic of Iran
}

Correspondence address: Mahmoud Reza KHALATBARI / E-mail: mrkhalatbari@hotmail.com

\begin{abstract}
Brown tumor is a bone lesion secondary to hyperparathyroidism of various etiologies. Skeletal involvement in primary hyperparathyroidism secondary to parathyroid adenoma is very uncommon and brown tumor has become extremely a rare clinical entity. Hyperparathyroidism is usually associated with high levels of serum calcium. Brown tumor as the only and initial symptom of normocalcemic primary hyperparathyroidism is extremely rare. Moreover, involvement of the skull base and the orbit is exceedingly rare. The authors would report three cases of brown tumor of the anterior skull base that were associated with true normocalcemic primary hyperparathyroidism. Clinical manifestations, neuroimaging findings, pathological findings, diagnosis and treatment of the patients are discussed and the relevant literature is reviewed.
\end{abstract}

KEYWORDS: Brown tumor, Skull base, Normocalcemia, Primary hyperparathyroidism

öz

Kahverengi tümör çeşitli etiyolojiler nedenli hiperparatiroidiye sekonder bir kemik lezyonudur. Paratiroid adenomuna sekonder primer hiperparatiroidide iskelet tutulumu çok nadirdir ve kahverengi tümör çok nadir bir klinik olay haline gelmiştir. Hiperparatiroidi genellikle yüksek serum kalsiyum düzeyleriyle ilişkilidir. Normokalsemik primer hiperparatiroidinin tek ve başlangıç belirtisi olarak kahverengi tümör çok nadirdir. Ayrıca kafatası tabanı ve orbitanın tutulması son derece nadirdir. Yazarlar gerçek normokalsemik primer paratiroidi ile ilişkili anterior kafatası tabanının üç kahverengi tümör vakasını sunmaktadır. Klinik bulgular, nörogörüntüleme bulguları, patolojik bulgular ve bu hastaların tanı ve tedavisi sunulmakta ve ilgili literatür gözden geçirilmektedir.

ANAHTAR SÖZCÜKLER: Kahverengi tümör, Kafatası tabanı, Normokalsemi, Primer hiperparatiroidi

\section{INTRODUCTION}

Brown tumor is a benign reactive destructive process of bone that occurs in patients with either primary or secondary hyperparathyroidism (HPT) $(1,2,9,10,12)$. The lesion appears to be relatively rare in the skull base and orbital region $(1,10$, 12). The skull base is composed of membranous bone and has little trabecular bone. Brown tumor usually occurs in the medullary shaft of long bones. Common locations for brown tumor include the mandible, maxilla, clavicle, metacarpal bones, ribs and pelvic bones and rarely the cranium and face (1). In fact, brown tumor has a minimal affinity for skull base bones. Multiple bone involvements are exceedingly rare in primary HPT and may be mistaken for clinical diagnosis of metastatic lesions $(3,9,11,18,26)$.

HPT is a clinical disorder characterized by increase in circulating concentration of parathyroid hormone (PTH) $(3,15,16,18,24)$. It is generally classified into primary, secondary, and tertiary depending on its etiology $(1,12,21)$. Primary HPT is usually due to a single parathyroid adenoma $(5,9,12,21)$. The most common presentation of primary HPT is hypercalcemia which is asymptomatic $(10,11)$. There are, however, instances where patients with primary HPT have normal total and/or ionized 
serum calcium levels or intermittent hypercalcemia $(5,15,16$, 24). Brown tumor is extremely rare in normocalcemic primary HPT $(2,5,6,8,24)$. Only 8 cases have been reported so far in the English literature (Table I).

The authors present three cases of brown tumors of the anterior skull base which were associated with true normocalcemic primary HPT and presented with brown tumor as the initial and sole manifestation of primary HPT. Clinical manifestations, neuroimaging findings, pathological findings, diagnosis and treatment of this unusual disorder are described and hypotheses of normocalcemia are discussed and the relevant literature is meticulously reviewed.

Table I: Summary of Brown Tumors in Normocalcemic Primary Hyperparathyroidism

\begin{tabular}{|c|c|c|c|c|}
\hline Authors/year & Age (year)/gender & Location of tumor & Symptoms & Imaging \\
\hline Cabot, 1978 (4) & $70 / F$ & Left ilium & pain & X-ray: lytic lesion \\
\hline $\begin{array}{l}\text { Sarda et al. } \\
1993 \text { (19) }\end{array}$ & $23 / F$ & T3 & $\begin{array}{l}\text { Pain + paraplegia } \\
+ \text { T3 gibbus }\end{array}$ & Myelogram: T3 block \\
\hline $\begin{array}{l}\text { Kocer et al. } \\
1994 \text { (14) }\end{array}$ & $7 / F$ & Left mandible & Mass & X-ray: Cystic mass \\
\hline $\begin{array}{l}\text { Unlu et al. } \\
2003 \text { (24) }\end{array}$ & $9 / \mathrm{M}$ & Left mandible & $\begin{array}{l}\text { Firm } \\
\text { mass }\end{array}$ & $\begin{array}{l}\mathrm{X} \text {-ray: radiolucent mass } \\
\mathrm{CT} \text { : lytic lesion with destruction }\end{array}$ \\
\hline $\begin{array}{l}\text { Suarez-Cunqueiro } \\
\text { et al. } 2004 \text { ( } 20)\end{array}$ & $26 / M$ & Right Mandible & Swelling & $\begin{array}{l}\text { X-Ray: multilocular radiolucent } \\
\text { lesion } \\
\text { CT: loculated bone expanding } \\
\text { lesion }\end{array}$ \\
\hline $\begin{array}{l}\text { Emin et al. } \\
2004(6)\end{array}$ & $62 / F$ & Left mandible & Mass, weakness, pain & CT: osteolytic lesion \\
\hline $\begin{array}{l}\text { Cebesoy et al. } \\
2007 \text { (5) }\end{array}$ & $43 / F$ & $\begin{array}{l}\text { Left foot } \\
\text { ( } 3^{\text {rd }} \text { metatarsal) }\end{array}$ & Swelling, pain & $\begin{array}{l}\text { X-ray: multiloculated radiolucent } \\
\text { lesion } \\
\text { MRI: multiloculated cystic lesion } \\
\text { Hypo- on T1 hyper-intense on T2 }\end{array}$ \\
\hline $\begin{array}{l}\text { Angadi et al. } \\
2010 \text { (2) }\end{array}$ & $38 / \mathrm{M}$ & Right mandible & Swelling & $\begin{array}{l}\text { X-ray: ill-defined radiolucent lesion } \\
\text { MRI: destructive soft tissue mass of } \\
\text { mandible hyper intense on } \mathrm{T} 2\end{array}$ \\
\hline Present case & $38 / F$ & Right orbitofrontal & Pain, proptosis, ptosis & $\begin{array}{l}\text { X-ray: multiple frontal lytic lesions } \\
\text { CT: destructive orbital roof } \\
\text { lesion with fluid-fluid level; } \\
\text { MRI: iso-intense on T1, non- } \\
\text { homogeneous hyper-intense on } \\
\text { T2, homogeneously enhanced }\end{array}$ \\
\hline Present case & $35 / F$ & $\begin{array}{l}\text { Left frontal sinus and } \\
\text { bone }\end{array}$ & $\begin{array}{l}\text { Pain, swelling and } \\
\text { mass }\end{array}$ & $\begin{array}{l}\text { CT: lytic destructive lesion on } \\
\text { frontal bone and sinus with } \\
\text { subgaleal extension } \\
\text { MRI: isointense on T1, } \\
\text { nonhomogeneous hyperintense } \\
\text { on T2, homogeneous } \\
\text { enhancement }\end{array}$ \\
\hline Present case & $65 / F$ & $\begin{array}{l}\text { Right lateral orbit } \\
\text { and temporalis fossa }\end{array}$ & $\begin{array}{l}\text { Pain, swelling, mild } \\
\text { proptosis }\end{array}$ & $\begin{array}{l}\text { CT: destructive lytic lesion of right } \\
\text { sphenoid bone and lateral orbit } \\
\text { MRI: isointense on T1, } \\
\text { nonhomogeneous hyperintense } \\
\text { on T2, homogeneously enhanced }\end{array}$ \\
\hline
\end{tabular}




\section{CASE REPORTS}

\section{Case 1}

A 38-year-old woman was admitted for evaluation of a painful mass in her right orbito-frontal region. She noticed the mass 4 days earlier which appeared suddenly and its size had increased progressively leading to right proptosis and globe deviation inferomedially. Three years earlier, the patient had presented with pain of her right proximal femur. Radiography revealed a large cystic lesion of her right proximal femur. For this reason, she underwent a biopsy and curettage of the lesion with bone graft. Pathological examination reported a giant cell tumor. At that time, serum calcium, phosphorus and alkaline phosphatase (ALP) were within normal ranges and she was not evaluated regarding the presence of HPT. Two years earlier, she once more presented with pain and a large mass of her left maxilla and underwent an excisional biopsy and left maxillotomy with reconstruction. The mass was diagnosed as a giant cell tumor. Again serum calcium, phosphorus, and ALP levels were within normal ranges and she was not evaluated for HPT.

The current examination revealed that the mass had caused right proptosis, ptosis and swelling of her right orbito-frontal region. Plain skull $x$-ray showed three lytic lesions in the frontal bone and destruction of the right orbital roof. Computed tomography (CT) scan of the brain and orbit showed an expansile lytic lesion of the right fronto-orbital area with erosion of the inner table of the skull and roof of the orbit with fluid-fluid level consistent with internal hemorrhage (Figure 1A). Magnetic resonance imaging (MRI) of the brain and orbit showed a large multiloculated, cystic extraaxial mass of the right orbito-frontal area, isointense on $T_{1}$ weighted $\left(T_{1} W\right)$ images and heterogeneous hyperintense on $\mathrm{T}_{2}$-weighted $\left(\mathrm{T}_{2} \mathrm{~W}\right)$ images with several fluid- fluid levels. The lesion extended into the superior orbit, causing depression of the globe and enhanced homogeneously after contrast medium injection (Figure 1B). Laboratory studies revealed normal serum levels of total calcium: $8.4 \mathrm{mg} / \mathrm{dL}$ (normal range: $8.2-10.6 \mathrm{mg} / \mathrm{dL}$ ); ionized (free) calcium: $5 \mathrm{mg} / \mathrm{dL}$ (normal range: 4 to $5.4 \mathrm{mg} / \mathrm{dL}$ ); phosphorus: $2.5 \mathrm{mg} / \mathrm{dL}$ (normal range: $2.5-4.8 \mathrm{mg} / \mathrm{dL}$ ) and ALP: $350 \mathrm{U} / \mathrm{L}$ (normal: 80 to 360). 24-hour urinary levels of calcium and $25-\mathrm{OH}$ Vitamin D: $12 \mathrm{ng} / \mathrm{mL}$ (normal: 10 to $55 \mathrm{ng} / \mathrm{mL}$ ) level were also normal. Other laboratory tests were within their normal ranges.

A cranio-orbitotomy was performed with complete excision of the lesion. Pathological examination of the specimen revealed a giant cell tumor. To rule out brown tumor, further investigation revealed high PTH level: 1,068 pg/mL (normal: 12-70 pg/mL). An ultrasonography of the neck showed a $17 \times 13 \mathrm{~mm}$ hypoechoic mass in the right thyroid lobe. MRI of the neck showed an adenoma involving the right superior parathyroid gland. Thallium parathyroid subtraction scintigraphy confirmed a parathyroid adenoma. The patient underwent a right superior parathyroidectomy and pathological examination confirmed the adenoma. Calcium and vitamin D supplementations were administered for her. Last follow-up after three years revealed that serum PTH level was normal and the patient did not have any complaint and her general health condition was good.
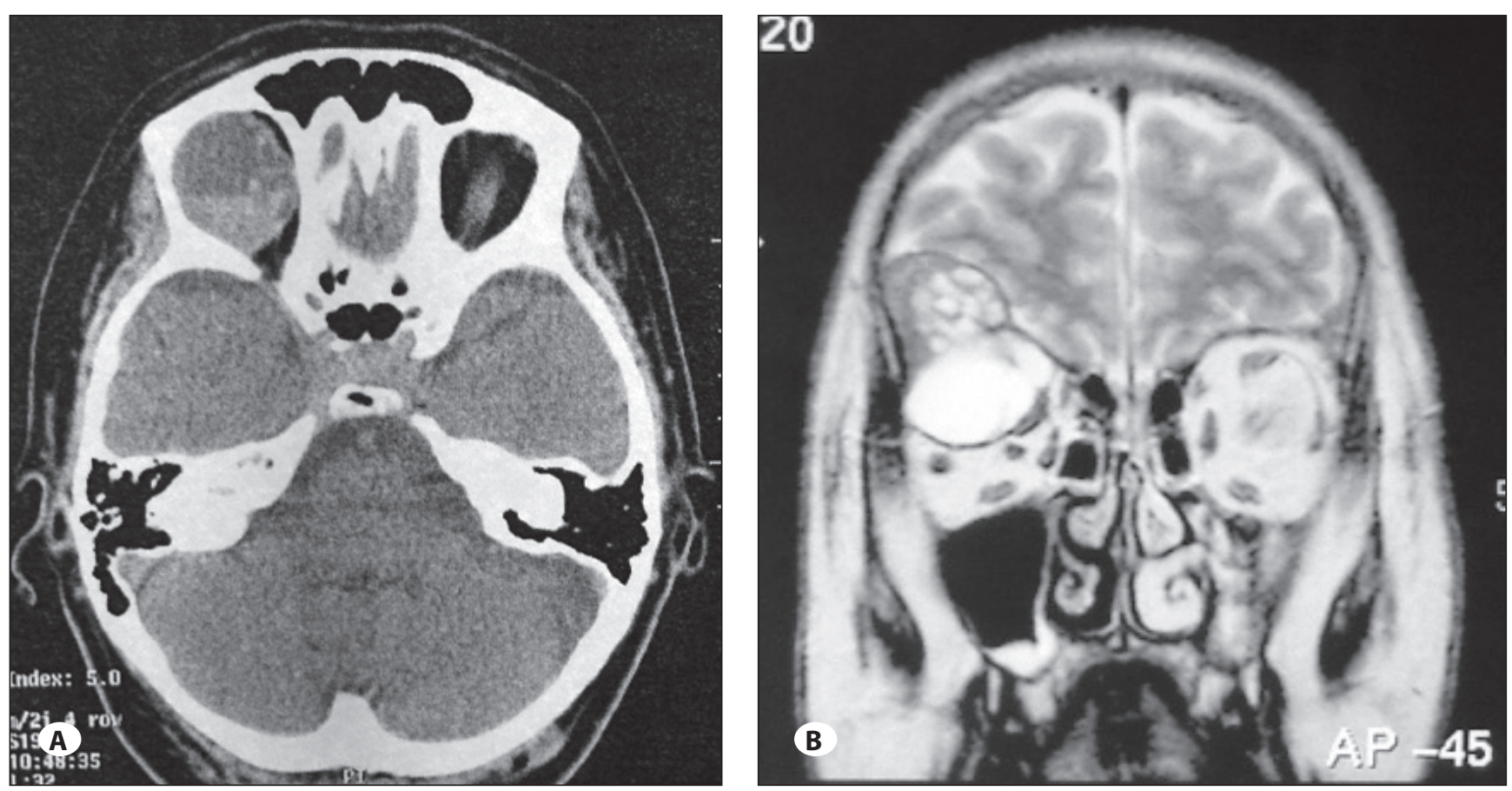

Figure 1: (A) CT scan of the brain and orbit showing an expansile lytic lesion of the right fronto-orbital area with erosion of the inner table of skull and roof of the orbit with fluid-fluid level consistent with internal hemorrhage. (B) Heterogeneous hyperintense lesion with several fluid- fluid levels and compression of globe on coronal T2-weighted images. 


\section{Case 2}

A 35-year-old woman was admitted with a complaint of pain and expanding left frontal mass for about 3 months. On examination, a subgaleal mass was found in the left frontal area just above the left orbital rim with mild proptosis. Otherwise, the neurological and physical examinations were normal. CT scan of the brain showed a destructive expansile lesion of the frontal sinus with erosion of both internal and external tables of the frontal bone and frontal sinus and left orbital roof and extension through the skull in the intracranial and subgaleal spaces (Figure $2 \mathrm{~A}$ ). MRI of the brain revealed a large frontal mass involving the frontal sinus, isointense on $\mathrm{T}_{1} \mathrm{~W}$ images and heterogeneous hyperintense on $\mathrm{T}_{2} \mathrm{~W}$ images with subgaleal extension. The lesion enhanced homogeneously after contrast medium injection (Figure $2 \mathrm{~B})$. Laboratory studies revealed normal serum levels of total calcium ( $8.8 \mathrm{mg} / \mathrm{dL})$, phosphorus $(2.4 \mathrm{mg} / \mathrm{dL}$ ), ionized (free) calcium (5 mg/dL), ALP (380 U/L), and 25-OH vitamin D: 8.4 $\mathrm{ng} / \mathrm{mL}$ (normal: 10 to $55 \mathrm{ng} / \mathrm{mL}$ ). Other laboratory tests were within their normal ranges.

An incision was done over the frontal mass and the lesion was removed. Pathological examination of the specimen revealed giant cell tumor. Serum PTH level was high: 680 $\mathrm{pg} / \mathrm{mL}$ (normal: $12-70 \mathrm{pg} / \mathrm{mL}$ ). Ultrasonography of the neck demonstrated an $11 \times 8 \mathrm{~mm}$ mass in posterior part of the left thyroid gland. MRI of the neck showed a parathyroid adenoma in the left inferior gland. Thallium parathyroid subtraction scintigraphy confirmed a parathyroid adenoma. After a left inferior parathyroidectomy, pathological examination of the resection showed a parathyroid adenoma. At follow-up after 4 years, serum PTH level was normal and the patient was in good condition.

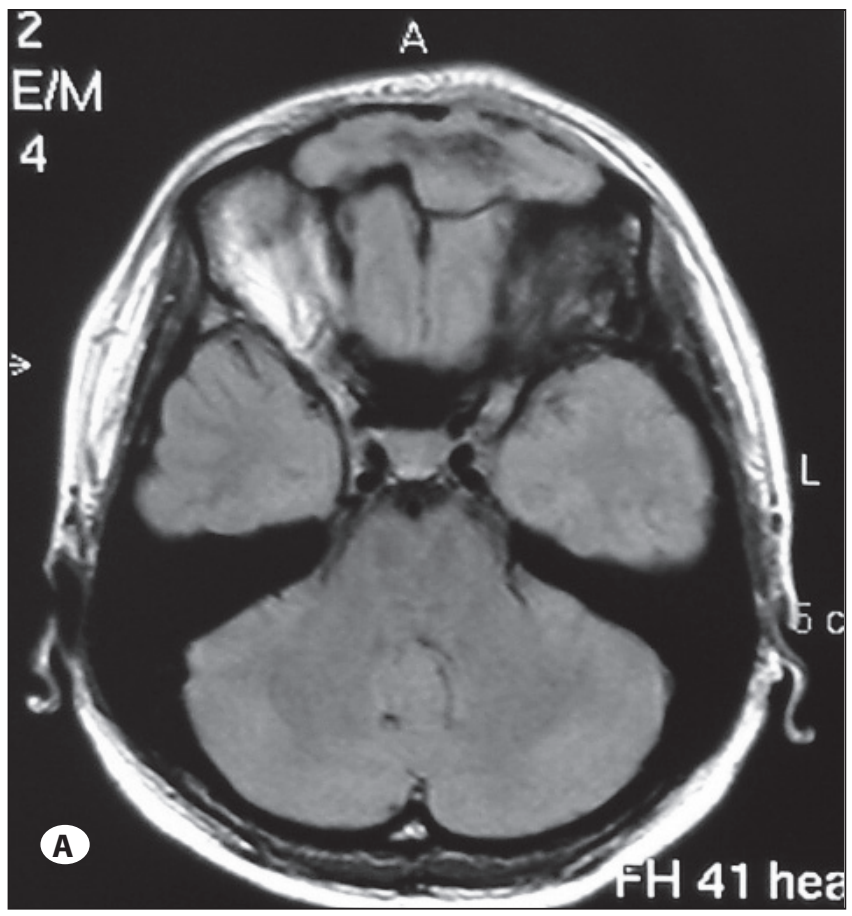

\section{Case 3}

A 65-year-old woman was referred for evaluation of a painful mass in the right lateral orbital wall and temporalis fossa that had developed four months earlier. The size of the mass had progressively increased and had caused mild proptosis. Physical examination showed a painful swelling on the right lateral orbital region and temporalis fossa. The results of the rest of the physical examinations were normal. CT scan of the brain revealed a well-defined bone-destroying mass involving the lateral wall and roof of the orbit. The mass was isodense with the brain parenchyma, had well-defined sclerotic border and invaded the lateral wall of the right orbit and temporalis fossa. The lesion mainly located on the greater wing of the sphenoid showed extensions into the zygomatic bone, temporalis fossa, and orbit. The MRI showed a hypointense signal on $T_{1} W$ images and nonhomogeneous hyperintense signal on $\mathrm{T}_{2} \mathrm{~W}$ images. Coronal section showed invasion into the anterior cranial fossa. The lesion enhanced homogeneously after contrast medium injection (Figure 3A, B). Laboratory evaluation revealed normal serum calcium (both total and ionized), normal phosphorus and ALP. 24-hour urinary calcium assay was normal and $25-\mathrm{OH}$ vitamin D level was $8 \mathrm{ng} / \mathrm{mL}$ (normal: 10 to $55 \mathrm{ng} / \mathrm{mL}$ ). Other laboratory tests were in their normal ranges.

The lesion was removed completely through a pterional (frontotemporosphenoidal) approach. The pathological examination revealed giant cell tumor. Further investigation disclosed a serum PTH value of $820 \mathrm{pg} / \mathrm{mL}$. Ultrasonography of the neck revealed an enlargement of the lower right parathyroid gland $(18 \times 11 \mathrm{~mm})$. MRI of the neck showed a parathyroid adenoma. Histo-pathologic examination of the surgically excised specimen confirmed the diagnosis



Figure 2: (A) An isointense lesion involving the frontal sinus with subgaleal extension on T1-weighted images. (B) Sagittal contrast-enhanced MRI shows homogeneous enhancement with subgaleal extension. 


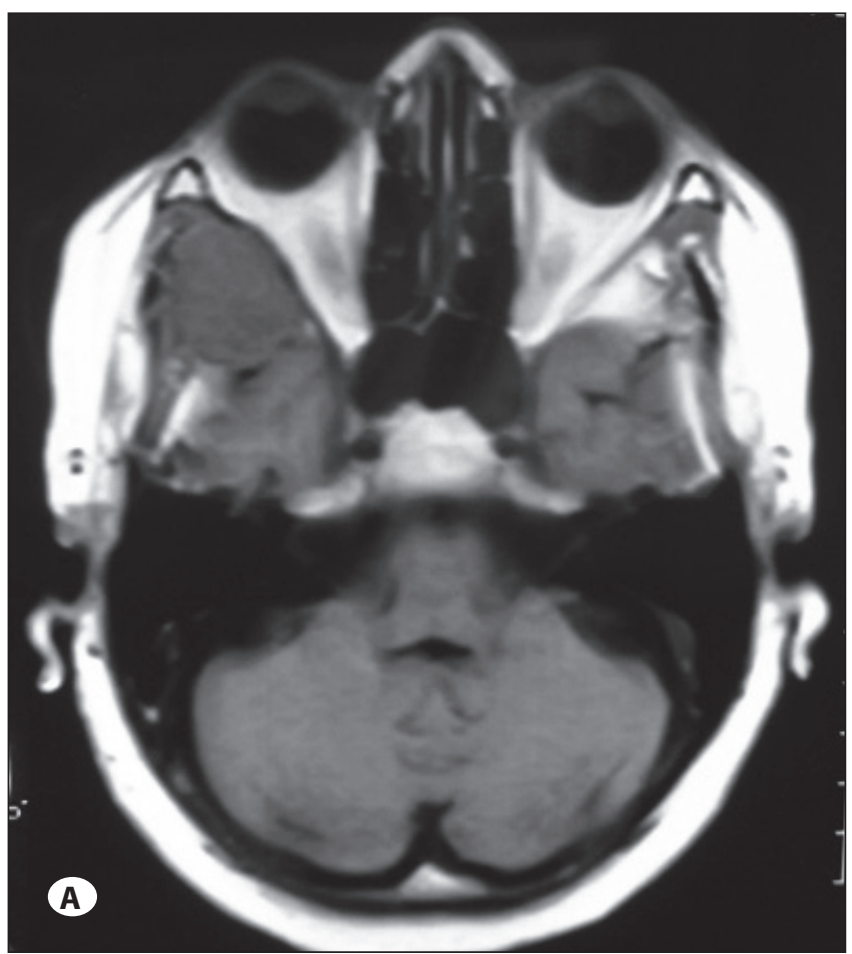

of parathyroid adenoma. The postoperative course was uneventful, and PTH levels returned to normal ranges and at 3 years after surgery, no recurrence of the tumor was detected.

\section{DISCUSSION}

The differential diagnoses of bone-expanding or lytic lesions in the skull base include plasmacytoma, metastatic lesions, fibrous dysplasia, primary bone tumors, inflammatory lesions and giant cell lesions. Bone expanding giant cell lesions that can arise in the skull base include true giant-cell tumor, aneurysmal bone cyst, giant cell reparative granuloma and brown tumor $(1,12,25,27)$.

Brown tumor represents localized accumulation of fibrous tissue and giant cells, which can replace bone and may even produce osseous expansion and subsequently undergo necrosis and liquefaction, producing cysts as a result of intraosseous bleeding and tissue degeneration (1, 5, 9-12).

These tumors are considered as the end-stage complication of HPT and are rarely the first presentation of the disease (25). They are relatively rare today, due to earlier diagnosis and prompt treatment of HPT, and are seen more often as a result of secondary HPT because of an increasing number of dialysis patients and their increased longevity $(1,9-13,23,24)$.

Multiple brown tumors as a result of primary HPT are very rare. Sahan et al. (18) reviewed the English literature and found six cases of multiple brown tumors in primary HPT. They themselves observed one another case. As far as we know, since then only four cases of multiple brown tumor in primary HPT have been added to the literature by Atabek et al. (3), Hoshi et al. (9), Sutbeyaz et al. (21), and Zhang et al. (26).

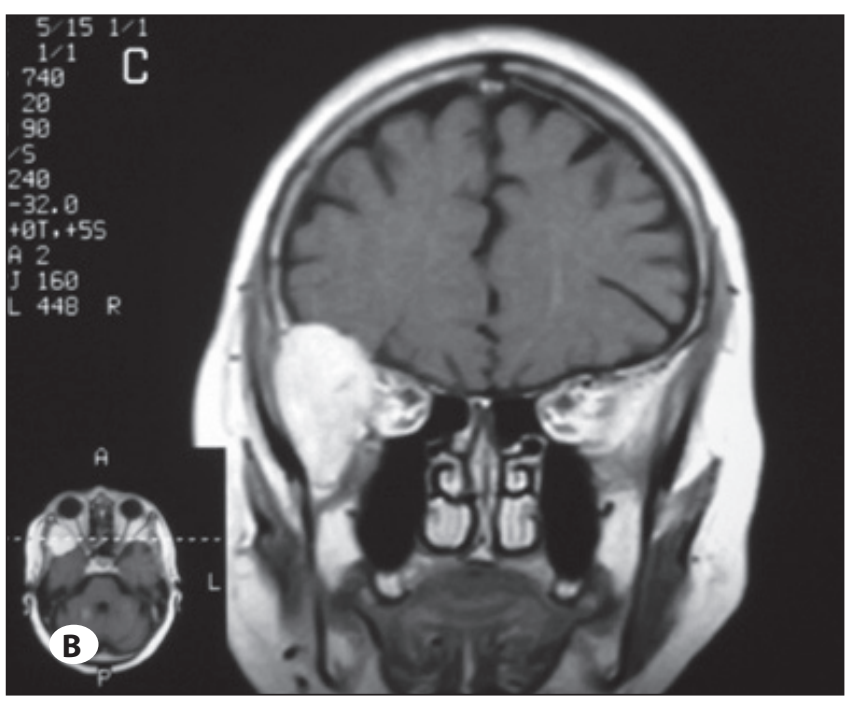

Figure 3: (A) An isosignal lesion involving the lateral orbital wall on T1-weighted MRI. (B) Coronal contrast-enhanced MRI demonstrates orbitofrontal lesion compressing the globe with homogeneous enhancement.

Our first case brings the number of multiple brown tumors in primary HPT patients to 12 cases. Only the current case had normocalcemic primary HPT with multiple brown tumors.

Involvement of the orbito-frontal region and the skull base is considered rare $(1,12,17,25,27)$. In the skull base, they usually involve one or more of the paranasal sinuses. The most commonly involved sinus is maxillary sinus and the frontal sinus is the least commonly involved, with the sphenoidal and ethmoidal sinuses lying somewhere in between (1). AlGahtany et al. (1) reviewed the literature and found 16 cases of skull base brown tumor including 8 cases of primary HPT. Since then, only three additional cases have been reported by Jebasingh et al. (10), Yilmazlar et al. (25), and Erem et al. (7) in patients with primary HPT. Our three cases bring the number of skull base brown tumors in primary HPT to 14 cases. Only our three cases occurred with normocalcemic primary HPT.

These tumors are usually soft, painless, minimally tender, and appear elastic on palpation (1, 5, 10, 24). Occasionally, the lesion is painful $(6,10,12)$, as was seen in our cases. The tumor is called "brown" because of its color, which is a result of vascularity, hemorrhage and deposit of hemosiderin $(5,6$, $9,12,23)$.

Most patients with primary HPT (80-85\%) show a single adenoma in one parathyroid gland whereas the other 3 glands are normal as was observed in our patients. Approximately $15 \%$ to $20 \%$ of patients have a pathological process (hyperplasia) involving all four parathyroid glands (9, $12,21,25)$.

Since the major action of PTH is to raise plasma calcium level, the main biochemical abnormality in primary HPT is 
an increase in the circulating concentrations of both PTH and calcium (16). Some patients with proven parathyroid adenoma have normal total and/or ionized serum calcium level or intermittent hypercalcemia $(15,16)$. Approximately $20 \%$ of patients with primary HPT are normocalcemic. When the ionized calcium concentration is normal, the term truly normocalcemic is applied. Approximately $20 \%$ of patients with normocalcemic primary HPT are true normocalcemic $(15,16)$, as in our cases.

Several hypotheses have been proposed to explain the persistently normocalcemia in primary $\operatorname{HPT}(15,16)$ :

1. In normocalcemic primary HPT, serum total calcium concentration is normal but, free (ionized), biologically relevant fraction of serum calcium is increased.

2. Normocalcemia in these patients may represent an early and/or a mild variety of primary HPT.

3. Normocalcemia could be the consequence of a renal tubular resistance to the action of PTH. Patients with normocalcemic primary HPT have a normal tubular reabsorption of calcium.

4. The mass of parathyroid adenoma is smaller in normocalcemic patients, thus, mean serum PTH concentration is lower.

5. A primary renal calcium leak leading to secondary hyperparathyroidism and eventually autonomous hyperparathyroidism has been proposed.

6. Concomitant vitamin D deficiency and/or insufficient calcium intake has been proposed to account for persistent normocalcemia in primary HPT.

7. Serum calcium levels before developing HPT is lower in these patients and that they increased but stay within the normal range.

Normal calcium (total and ionized) level, low normal serum vitamin $\mathrm{D}$ level and the presence of multiple brown tumors show the coincidence of osteoporosis and long and severe primary HPT in our first case. Normal calcium (total and ionized) level, low serum vitamin D and brown tumor show the coincidence of primary HPT with vitamin D deficiency in our second and third cases. Parathyroid adenoma and high PTH level indicate the presence of primary HPT. Vitamin D deficiency, osteomalacia, and osteoporosis are common findings in developing countries and when compounded by primary HPT, become a diagnostic challenge and a cause of apparent normocalcemic HPT. The majority of patients with normocalcemic primary HPT have a history of urinary tract stone and/or hypercalciuria, but brown tumor without renal calculi also occur in these patients $(8,19,24)$, as was observed in our patients.

The diagnosis of HPT should be established by determination of the serum calcium, phosphorus, ALP, and PTH level rather than by histological examination of focal lesion. The main challenge in diagnosing brown tumor is that it can be seen in normocalcemic patients as well (5), as in our cases. Histologically, brown tumors are non-encapsulated and are characterized by abundant stroma consisting of fibrous connective tissue, with an important proliferation of fibroblasts and several multinucleated osteoclast-like giant cells containing variable numbers of nuclei. Calcified material and areas with extravasations of red blood cell and hemosiderin in histiocyte can be found $(9,11,12,22-25)$.

The clinical features of calvarial brown tumors are non-specific and depend on their size and location. Headache, swelling, and ophthalmological symptoms such as diplopia, ptosis, decreased visual acuity, decreased extraocular movement, proptosis and pain are the most common symptoms associated with skull base brown tumors $(1,12,17,23,25,27)$.

Radiographically, brown tumors are usually well-defined purely lytic unilocular or multilocular lesions that stimulate little reactive bone formation $(22,26)$. The pathologically similar giant cell tumors often have indistinct borders and blend into the normal bone, a finding that may serve to distinguish them from brown tumors $(1,10,11,12,22-24)$. Characteristic radiographic finding of HPT can also be found in patients with brown tumors such as widespread loss of lamina dura, and subperiosteal erosion of phalanges $(2,22$, $23,25)$. However, occasionally a solitary brown tumor is the only skeletal manifestation of HPT (22), as in our cases two and three. On CT scan, brown tumors appear as a lytic lesion with associated soft tissue mass. The lesion may be hyperdense or heterogeneous, and well-circumscribed or expansile lucent lesion with a rim of calcification and remodeling of surrounding bone. After injection of contrast medium, brown tumors appear as heterogeneously enhancing masses (1, $9,11,13,22-25,27)$. There is no periosteal reaction or soft tissue invasion $(11,22)$. The appearance on CT is not specific, and metastasis or myeloma may have a similar appearance $(13,26)$. The brown tumor may demonstrate fluid-fluid level consisting with internal hemorrhage on $\operatorname{CT} \operatorname{scan}(9,27)$, as was seen in our first patient.

On MR imaging, brown tumors usually have hypointense signal on $T_{1} W$ images, variable signal on $T_{2} W$ images, and loss of signal on in-phase images because of magnetic susceptibility related to hemosiderin, osteoid matrix or air within the tissue $(9,13,22,23)$. Brown tumors enhance intensely after contrast injection $(1,9,13,22,23)$. The early and intense enhancement is due to rich vascularity (22). The wide spectrum features of brown tumor on MRI depend on the pathologic background and tissue component of tumor such as cystic area, hemorrhage, fibrous stroma, and hemosiderin deposition $(13,22,23)$. Repeated episode of intratumoral hemorrhage led to fluid-fluid levels (22), as in our cases.

When an osteolytic lesion of the skull base is diagnosed, especially when it is a giant cell tumor, even with a normal serum calcium level, PTH assay is necessary to exclude HPT. Treatment of brown tumor should start with treatment of HPT (removal of offending adenoma) and if persisted after this primary treatment, enucleation and curettage should 
be added. Compressive lesions with neural compromise, functional problem and fracture may require early surgical removal $(1,2,5,9,10,12,21-23,25)$. Sometimes, surgery is indicated for definitive tissue diagnosis. In patients with primary HPT or normocalcemia, in whom the brown tumor is the first manifestation, biopsy is necessary (1).

There is limited evidence about natural history of brown tumor in the skull base. According to a report, brown tumor of the ethmoidofrontal skull base, in a 38-year-old woman with parathyroid adenoma who underwent parathyroid adenectomy, underwent extensive calcification after 6 years and the patient became asymptomatic. This pattern has been reported in other parts of the skeleton. When parathyroid adenoma is removed and consequently serum level of parathormone and calcium decrease, brown tumors rarely progress (1).

In conclusion, brown tumors of the anterior skull base region are rare. They are extremely rare in normocalcemic primary HPT. The point in reporting these cases is that they may be the first clinical sign of HPT. To prevent unnecessary surgical procedures, PTH assay is necessary in any patient with expansive-lytic lesion or giant cell tumor of the skull base.

\section{ABBREVIATIONS}

PTH = parathyroid hormone, $\mathbf{H P T}=$ hyperparathyroidism, ALP $=$ alkaline phosphatase.

\section{REFERENCES}

1. Al-Gahtany $M$, Cusimano $M$, Singer W, Bilbao J, Kovacs $K$, Marotta T: Brown tumor of the skull base: Case report and review of the literature. J Neurosurg 98:417-420, 2003

2. Angadi PV, Rekha K, Shetty SR: An exophytic mandibular brown tumor: An unusual presentation of primary hyperparathyroidism. Oral maxillofac Surg 14: 67-69, 2010

3. Atabek ME, Pirgon O, Sert A, Esen HH: Extensive brown tumors caused by parathyroid adenoma in an adolescent patient. Eur J Pediatr 167:117-119, 2008

4. Cabot RC: Brown tumor in a normocalcemic woman. N Engl J Med 298:266-274, 1978

5. Cebesoy O, Karakok M, Arpacioglu D, Baltaci ET: Brown tumor with atypical localization in a normocalcemic patient. Arch Orthop Trauma Surg 127:577-580, 2007

6. Emin $A H$, Suoglu $Y$, Demir D, Karatay MC: Normocalcemic hyperparathyroidism presented with mandibular brown tumor: Report of a case. Auris Nasus Larynx 31:299- 304, 2004

7. Erem C, Hacihasanoglu A, Cinel A, Ersoz HO, Reis A, Sari A, Kose M, Ukinc K, Telatar M: Sphenoid sinus brown tumor, a mass lesion of occipital bone and hypercalcemia: An unusual presentation of primary hyperparathyroidism. J Endocrinol Invest 27:366-369, 2004

8. Frame B, Foroozanfar F, Patton RB: Normocalcemic primary hyperparathyroidism with osteitis fibrosa. Ann Intern Med 73: 253-257, 1970

9. Hoshi M, Takami M, Kajikawa M, Teramura K, Okamoto $T$, Yanagida I, Matsumura A: A case of multiple skeletal lesions of brown tumors, mimicking carcinoma metastases. Arch Orthop Tuauma Surg 128:149-154, 2008
10. Jebasingh F, Jacob JJ, Shah A, Paul TV, Seshadri MS: Bilateral maxillary brown as the first presentation of primary hyperparathyroidism. Oral Maxillofac Surg 12:97-100, 2008

11. Jouan A, Zabraniecki L, Vincent V, Poix E, Fournie B: An unusual presentation of primary hyperparathyroidism: Severe hypercalcemia and multiple brown tumors. Joint Bone Spine 75: 209-211, 2008

12. Kanaan I, Ahmed M, Rifai A, Alwatban J: Sphenoid sinus brown tumor of secondary hyperparathyroidism: Case report. Neurosurgery 42:1374-1377, 1998

13. Knowles NG, Simith DL, Outwater EK: MRI diagnosis of brown tumor based on magnetic susceptibility. J Magn Reson Imaging 28:759-761, 2008

14. Kocer U, Percin AK, Sensoz O, Celebioglu S: Brown tumor in normocalcemic child. Eur J Plast Surg 17:28-30, 1994

15. Lowe H, Mcmahon DJ, Rubin MR, Bilezikian JP, Silverberg SJ: Normocalcemic primary hyperparathyroidism: Further characterization of a new clinical phenotype. J Clin Endocrinol Metab 92:3001-3005, 2007

16. Maruani G, Hertig A, Paillard M, Houillier P: Normocalcemic primary hyperparathyroidism: Evidence for a generalized target-tissue resistance to parathyroid hormone. J Clin Endocrinol Metab 88:4641-4648, 2003

17. Monterio MLR: Multiple brown tumors of the orbital walls: Case report. Arq Bras Oftalmol 72:116-118, 2009

18. Sahan MH, Guner S, Guner SI: Radiological finding in the primary hyperparathyroid case with multiple brown tumors; A case report. East J Med 13:30-34, 2008

19. Sarda AK, Arunabh, Vijayaraghavan M, Kapur M: Paraplegia due to osteitis fibrosa secondary to primary hyperparathyroidism: Report of a case. Surg Today 23:1003-1005, 1993

20. Suarez-Cunqueiro MM, Schoen R, Kersten A, Klisch J, Schmelzeisen R: Brown tumor of the mandible as first manifestation of atypical parathyroid adenoma. J Oral Maxillofac Surg 62:1024-1028, 2004

21. Sutbeyaz Y, Yoruk O, Bilen H, Gursan N: Primary hyperparathyroidism presenting as a palatal and mandibular brown tumor. J Craniofac Surg 20:2101-2104, 2009

22. Takeshita T, Takeshita K, Abe S, Takami H, Imamura T, Furui S: Brown tumor with fluid- fluid levels in a patient with primary hyperparathyroidism: Radiological finding. Radiat Med 24: 631-634, 2006

23. Takeshita T, Tanaka H, Harasawa A, Kaminaga T, Imamura T, Furui S: Brown tumor of the sphenoid sinus in a patient with secondary hyperparathyroidism: CT and MR imaging findings. Radiat Med 22:265-268, 2004

24. Unlu RE, Abaci E, Kerem M, Aksoy E, Sensoz O: Brown tumor in children with normocalcemic hyperparathyroidism: A report of two cases. J Craniofac Surg 14:69-73, 2003

25. Yilmazlar S, Arslan E, Aksoy K, Tolunay S: Sellar-parasellar brown tumor: Case report and review of literature. Skull Base $14: 163-168,2004$

26. Zhang HL: Multiple brown tumors: A diagnostic dilemma. The Endocrinologist 20:152-154, 2010

27. Zwick OM, Vagefi MR, Cockerham KP, McDermott MW: Brown tumor of secondary hyperparathyroidism involving the superior orbit and frontal calvarium. Ophthal Plast Reconstr Surg 22:304-306, 2006 